\title{
Study on energy metabolism of dairy buffalo heifers in Guangxi, China*
}

\author{
C.X. Zou ${ }^{1,2}$, X.W. Liang ${ }^{2,4}$, B.Z.Yang ${ }^{2}$, K. Liang ${ }^{2}$, J.X. Liu ${ }^{1,4}$, \\ Z.S. Xia ${ }^{3}$, F. Zhao ${ }^{3}$ and S.J. Wei ${ }^{2}$ \\ ${ }^{1}$ Institute of Dairy Science, Zhejiang University \\ Hangzhou 310029, P.R. China \\ ${ }^{2}$ Buffalo Research Institute, Chinese Academy of Agricultural Sciences \\ Nanning 530001, P.R. China \\ ${ }^{3}$ Guangxi University \\ Guangxi 530005, P.R. China
}

\begin{abstract}
Twelve dairy buffalo heifers aged 12-15 months with a body weight of $220 \mathrm{~kg}$, were used in a randomized complete block design to study energy metabolism. The whole experiment consisted of 2 feeding trials with $20 \mathrm{~d}$ in-between interval, each including a digestion-metabolism trial. Animals were assigned to three levels of dietary net energy. Digestibility and metabolizability of energy were $67.1-71.4 \%$ and $55.1-59.2 \%$. Methane loss was $9.9-10.0 \%$ of gross energy intake, heat production and heat increment were 0.534 and $0.203 \mathrm{MJ} / \mathrm{kgW}^{0.75} / \mathrm{d}$, respectively. Net energy for growth was between $23.2-29.1 \%$ of gross energy.
\end{abstract}

KEY WORDS: energy metabolism, dairy buffalo heifer

\section{INTRODUCTION}

There are numerous papers on diet energy requirement for animals, such as pig, poultry, goat, sheep and cattle. To our knowledge, there is little available information from experimental studies on the energy metabolism of dairy buffalo heifers. Recently, the maintenance energy requirement of buffalo is referred to the same as for cattle (Yang et al., 2005). Actually, there are lots of difference between the physical parameters of buffalo and cattle. Thus, it is necessary to do some

\footnotetext{
* Supported by Guangxi Science Foundation, Grant No. 200447023

${ }^{4}$ Corresponding authors: e-mail: liangbri@126.com; e-mail: liujx@zju.edu.cn
} 
experiments on buffalo energy metabolism. The aim of the present experiment was to study energy metabolism of dairy buffalo heifers through feeding, digestion and respiratory gas metabolism trials.

\section{MATERIAL AND METHODS}

Animals, diets, and experimental design

Twelve dairy buffalo heifers aged 12-15 months (BW $220 \pm 12 \mathrm{~kg}$ ) were used in a randomized complete block design. Animals were divided into 3 groups based on body weight and breed, each group including 1 Chinese Nili-Ravi, 1 Chinese Murrah and 2 crossbred (Nili-Ravi $\times$ Murrah $\times$ local) buffaloes.

Experimental buffaloes were fed individually (twice daily, 08.00 and 14.00) and all animals had free access to the drinking water. Three isonitrogenous diets (I, II and III) were formulated to contain 3 levels of energy in NE for lactation $(8.00,7.50$ and $7.00 \mathrm{MJ} / \mathrm{kg})$. The elephant grass and pineapple were the main ingredients as forage. The ingredients and composition of the experimental diets are presented in Table 1. Each animal was offered $3 \mathrm{~kg}$ concentrate per day.

The whole experiment consisted of 2 feeding trials with 20 days in-between interval, each including a digestion-metabolism trial. Each feeding trial lasted for 30 days, following 15 days for adaptation to the diet. And a 7-day digestion and 3-d respiratory gas metabolism trials were conducted on the 24 and 28th day of feeding trial, respectively. The oxygen and carbon dioxide content were determined for 4 times per day per head $(06.00,12.00,18.00,24.00$, respectively) during the gas metabolism trial, and the temperature and pressure of atmosphere in experimental fields were also recorded at the beginning and end of gas determination (Guo, 1983).

\section{Samplings, measurements and analysis}

Live body weights were recorded for two consecutive days before morning feeding at the beginning and end of feeding/digestion-metabolism trial, respectively. Feeds offered $(08.00,14.00)$ and refused $(13.00,17.00)$ by individual buffaloes were weighed after each feeding and removed. Forage and concentrates were sampled weekly. All samples were immediately dried in an air-forced oven at $65^{\circ} \mathrm{C}$ for $48 \mathrm{~h}$ and stored in sealed plastic containers at room temperature until analysed. Dried forages and concentrates were ground firstly through a $2 \mathrm{~mm}$ screen, then through a $1 \mathrm{~mm}$ screen in a cycloter mill and analysed for dry matter (DM), crude protein (CP) and gross energy (GE) (PARR 6200).

During digestion-metabolism trial, the total faeces and urine were collected and recorded at 08.00 before morning feeding and urine/faeces samples were 
Table 1. Ingredient and composition of the experimental diets

\begin{tabular}{|c|c|c|c|}
\hline \multirow[b]{2}{*}{ Item } & \multicolumn{3}{|c|}{ Diet } \\
\hline & $\mathrm{I}$ & II & III \\
\hline \multicolumn{4}{|l|}{ Ingredient, $\mathrm{kg} / \mathrm{d}$, as is basis } \\
\hline concentrate mixture & 3.0 & 3.0 & 3.0 \\
\hline fresh elephant grass & 12 & 12 & 12 \\
\hline fresh pineapple & 8 & 8 & 8 \\
\hline \multicolumn{4}{|c|}{ Ingredients of concentrate, \% of DM } \\
\hline ground maize grain & 55 & 48 & 40 \\
\hline wheat bran & 6 & 14 & 18 \\
\hline rapeseed meal & 22.5 & 18 & 17 \\
\hline soyabean meal & 10 & 12 & 12.8 \\
\hline limestone & 0.5 & 1 & 1 \\
\hline dicalcium phosphate & 2 & 2 & 2 \\
\hline salt & 1 & 2 & 2 \\
\hline premix & 3 & 3 & 3 \\
\hline medical stone & 0 & 0 & 4.2 \\
\hline \multicolumn{4}{|c|}{ Nutritional value of concentrate } \\
\hline crude protein, $\% \mathrm{DM}$ & 17.5 & 17.5 & 17.5 \\
\hline $\mathrm{NE}_{1}, \mathrm{MJ} / \mathrm{kg}$ & 8.00 & 7.50 & 7.00 \\
\hline
\end{tabular}

$\mathrm{NE}_{1}$ - Net energy for lactation

acidified immediately after collection by diluting 1 volume of urine/faeces with $10 \%$ volumes of $10 \% \mathrm{H}_{2} \mathrm{SO}_{4}$ and stored at $-20^{\circ} \mathrm{C}$. Samples were thawed at room temperature and analysed for urinary (UE) and faecal energy (FE). Oxygen, carbon dioxide concentration and total exchange gas amount were recorded during gas metabolism trial. Heat production (HP) was calculated from oxygen consumption $\left(\mathrm{O}_{2}\right)$, carbon dioxide production $\left(\mathrm{CO}_{2}\right)$ and urinary nitrogen loss $(\mathrm{Un})$ using the following formula (Brouwer, 1965):

$$
\mathrm{HP}(\mathrm{KJ})=16.1753 \mathrm{O}_{2}+5.0208 \mathrm{CO}_{2}-5.9873 \mathrm{Un} \text {. }
$$

Estimation of methane was based on Brouwer (1965).

\section{Statistical analyses}

Statistical analyses of the obtained data in the experiment were performed using Excel 2003 and the data are presented as means. 


\section{RESULTS AND DISCUSSION}

Ingredient and composition of the experimental diets are showed in Table 1. Contents of DM, CP and GE were 23 and $11.43 \%, 6.42$ and $6.78 \%$ of DM and 16.4 and $15.6 \mathrm{MJ} / \mathrm{kgDM}$ for elephant grass and pineapple, respectively.

Results of energy metabolism of experimental buffaloes are summarized in Tables 2 and 3. Although the designed energy values of three diets were different, the actual dietary GE intakes were similar. Maybe the experimental diet affects the diet intake. More energy was lost from faeces than from urine. The ratio of digestible energy (DE) to GE varying from 70.3 to $73.0 \%$ in early stage (12-13 months) was higher than that from 66.6 to $67.4 \%$ in late stage (14-15 months).

Table 2. Intake dry matter (DMI), gross (GE), digestible (DE) and metabolizable energy (ME), losses of energy in urine (UE) and methane $\left(\mathrm{CH}_{4}\right)$, and digestibility and metabolizability of energy in buffaloes

\begin{tabular}{|c|c|c|c|c|c|c|c|c|}
\hline \multirow{2}{*}{ Item } & \multicolumn{3}{|c|}{ First trial } & \multirow{2}{*}{ Mean } & \multicolumn{3}{|c|}{ Second trial } & \multirow{2}{*}{ Mean } \\
\hline & $\mathrm{I}$ & II & III & & $\mathrm{I}$ & II & III & \\
\hline$\overline{\mathrm{BW}}, \mathrm{kg}$ & 219 & 220 & 223 & 223 & 260 & 261 & 264 & 262 \\
\hline DMI, kg & 5.21 & 5.49 & 5.38 & 5.38 & 5.81 & 6.03 & 5.84 & 5.89 \\
\hline \multicolumn{9}{|c|}{ Energy metabolism, MJ } \\
\hline GE intake & 83.76 & 87.41 & 83.91 & 85.03 & 94.22 & 96.82 & 93.94 & 94.99 \\
\hline DE intake & 61.13 & 61.45 & 59.43 & 60.67 & 63.47 & 65.21 & 62.27 & 63.75 \\
\hline UE & 1.56 & 1.94 & 1.863 & 1.79 & 1.87 & 2.23 & 2.07 & 2.05 \\
\hline $\mathrm{CH}_{4}$ & 8.30 & 8.74 & 8.57 & 8.54 & 9.25 & 9.60 & 9.30 & 9.39 \\
\hline & & $---\%$ & ---- & & & 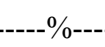 & ----- & \\
\hline $\mathrm{DE} / \mathrm{GE}$ & 73.0 & 70.3 & 70.8 & 71.4 & 67.4 & 67.4 & 66.60 & 67.1 \\
\hline $\mathrm{ME} / \mathrm{GE}$ & 61.2 & 58.1 & 58.4 & 59.2 & 55.6 & 55.1 & 54.5 & 55.1 \\
\hline $\mathrm{ME} / \mathrm{DE}$ & 83.6 & 82.6 & 82.5 & 83.0 & 82.5 & 81.9 & 81.8 & 82.1 \\
\hline UE/GEI & 1.9 & 2.2 & 2.2 & 2.1 & 2.0 & 2.3 & 2.2 & 2.1 \\
\hline $\mathrm{CH}_{4} / \mathrm{GE}$ & 9.9 & 10.0 & 10.2 & 10.0 & 9.8 & 9.9 & 9.9 & 9.9 \\
\hline
\end{tabular}

The ratio of metabolizable energy (ME) to DM in the two periods were not different, i.e. $82.1-83.0 \%$, similar to that for dairy cattle (82\%) (China Ministry of Agriculture, 2004), but higher than the results of lactating buffaloes (80.2\%) (Wen et al., 2003). It is suggested that efficiency with which the DE is converted to ME is higher in buffalo heifers than in lactating buffaloes.

Loss as methane was estimated based on DM intake (Brouwer, 1965), i.e. intake of $1 \mathrm{~kg}$ DM produces 401 methane, 11 methane is 0.714 gram, and 1 gram of methane's calorie is $64.032 \mathrm{KJ}$. From the data in Table 2, it was found that methane loss was about $10 \%$ of total energy intake in dairy buffalo heifers.

In ruminants, $76-86 \%$ of the $\mathrm{DE}$ is converted to $\mathrm{ME}$, and only $30-65 \%$ of the $\mathrm{ME}$ is converted to net energy (China Ministry of Agriculture, 2004). However, the ratio of ME to DE was $82.1-83.0 \%$, and ratio of net energy to ME was 74.0 - 
Table 3. Energy lost as heat production (HP), heat increment (HI), intake of net energy (NE) and NE used for maintenance (NEm) and growth (NEg) in buffaloes

\begin{tabular}{|c|c|c|c|c|c|c|c|c|}
\hline \multirow{2}{*}{ Item } & \multicolumn{3}{|c|}{ First feeding trial } & \multirow{2}{*}{ Mean } & \multicolumn{3}{|c|}{ Second feeding trial } & \multirow{2}{*}{ Mean } \\
\hline & I & II & III & & I & II & III & \\
\hline \multicolumn{9}{|c|}{ Energy metabolism, MJ } \\
\hline ME & 51.27 & 50.77 & 49.00 & 50.35 & 52.35 & 53.38 & 51.20 & 52.31 \\
\hline $\mathrm{NE}$ & 39.34 & 38.21 & 37.28 & 38.61 & 39.91 & 40.18 & 37.91 & 39.10 \\
\hline $\mathrm{NEm}^{\mathrm{a}}$ & 24.35 & 23.60 & 23.91 & 23.95 & 26.82 & 26.93 & 27.12 & 26.95 \\
\hline NEg & 14.99 & 15.61 & 13.38 & 14.66 & 12.39 & 13.26 & 10.80 & 12.15 \\
\hline \multirow[t]{2}{*}{$\mathrm{HI}$} & 11.93 & 11.56 & 11.71 & 11.73 & 13.14 & 13.19 & 13.29 & 13.21 \\
\hline & \multicolumn{4}{|c|}{------MJ/kgW } & \multicolumn{4}{|c|}{---MJ/kgW $0.75 / \mathrm{d}-----$} \\
\hline HP & 0.53 & 0.53 & 0.53 & 0.53 & 0.53 & 0.53 & 0.53 & 0.53 \\
\hline \multirow[t]{2}{*}{ HI } & 0.203 & 0.203 & 0.203 & 0.203 & 0.203 & 0.203 & 0.203 & 0.203 \\
\hline & -------- & $\%$ & --- & & & $0^{-}-\cdots$ & & \\
\hline $\mathrm{NEg} / \mathrm{GE}$ & 17.9 & 17.9 & 15.9 & 17.2 & 13.2 & 13.7 & 11.5 & 12.8 \\
\hline $\mathrm{NEm} / \mathrm{GE}$ & 29.1 & 27.0 & 28.5 & 28.2 & 28.5 & 27.8 & 28.9 & 28.4 \\
\hline $\mathrm{HI} / \mathrm{GE}$ & 14.2 & 13.2 & 14.0 & 13.8 & 13.9 & 13.6 & 14.1 & 13.9 \\
\hline NE/ME & 77.1 & 75.3 & 76.1 & 76.2 & 76.2 & 75.3 & 74.0 & 75.2 \\
\hline NEg/ME & 29.2 & 30.8 & 27.3 & 29.1 & 23.7 & 24.8 & 21.1 & 23.2 \\
\hline
\end{tabular}

${ }^{a}$ the NEm value was based on the fasting heat production (FHP) value in our lab experiment, i.e. for 15-month buffalo, $\mathrm{FHP}=0.331 \mathrm{MJ} / \mathrm{kgW}^{0.75} / \mathrm{d}, \mathrm{NEm}=\mathrm{FHP} * 125 \%$ (Yang et al., 2005)

$77.1 \%$ with dairy buffalo heifers (Table 3 ), suggesting that buffalo heifers may utilize the ME at higher efficacy.

\section{CONCLUSIONS}

Digestibility and metabolizability of energy were $67.1-71.4 \%$ and 55.1$59.2 \%$, methane loss was $9.9-10.0 \%$ of gross energy in dairy buffalo heifers. Heat production and heat increment were 0.534 and $0.203 \mathrm{MJ} / \mathrm{kgW}^{0.75} / \mathrm{d}$, respectively.

\section{REFERENCES}

Brouwer E., 1965. Energy Metabolism. EAAP Publication No. 11. Academic Press, London, pp. 441

China Ministry of Agriculture, 2004. Feeding Standard of Dairy Cattle, No. NY/T 34-2004. Ministry of Agriculture, Beijing (China)

Guo C., 1983. Study on the respiration experimental installation of livestock energy metabolism. China J. Anim. Sci. 19 (5), 8-11

Wen Q.Y., Huang F., Guan Y.Y., Fang W.Y., Chen M.T., 2003. Studies on conversion of diet energy of lactating buffaloes. China Herbivores 23 (1), 6-7

Yang B.Z., Wen Q.Y., Liang X.W., Zou C.X., Qin G.S., 2005. Fasting metabolism of dual-purposed buffaloes in different growth periods. China J. Anim. Sci. 41 (11), 46-48 